\title{
KRUKENBERG'S SPINDLES
}

\author{
BY
}

J. D. M. CARDELL, M.B., F.R.C.S.

LONDON

\section{Description of a Case}

This example of the condition occurred in a single woman, aged 30 years, with no family history of myopia, and no history of any previous inflammation of the eyes. Her corneae presented vertical spindle-shaped opacities, seen faintly on observing the red reflex, occupying an area of about $1.5 \times 3 \mathrm{~mm}$. in each eye, and situated below the horizontal meridian. On examination with the loupe, the opacities were found to be caused by a brown pigmentation in the corneae.

The pupils reacted normally to light, the irides were of a grey colour showing no signs of past or present inflammation, and no signs of a persistent pupillary membrane. There were no gross changes in the right fundus, but the left eye, which was the more highly myopic, showed an area of choroidal atrophy to the outer side of the disc. The vision of the right eye was J. 1 and less than $6 / 60$, in the left J. 20 and less than $6 / 60$, the refraction of the former being $-10 \mathrm{D}$. sph., and of the latter $-20 \mathrm{D}$. sph.

Miss Mann examined the case with the slit-lamp, and described the pigment as being almost on Descemet's membrane but on an anterior plane, and composed of a multitude of closely set rings with clear centres.

\section{Historical}

There have been about 21 cases of this condition described since 1899 when Krukenberg reported his first case. Vogt recently was able to collect some four cases for a clinical demonstration at Munich. A very complete review of the condition by $\mathbf{T}$. B. Holloway appeared in the "Annals of Ophthalmology" of 1920, whence a large amount of the information given below was obtained.

\section{Classifications of the Characters of Ten Cases}

(1) The distribution of the pigment: Bilaterally symmetrical ovals (except one case) in the deeper layers of the cornea, the long axes being vertical (except in one case where they were horizontal), the appearance being granular.

(2) The size of the spindles: from $2.5 \times 1$ to $4.25 \times 3.25 \mathrm{~mm}$.

(3) The colour of the pigment : from golden brown to chocolate.

(4) The colour of the iris: brown in five, grey in five. 
(5) Associated lesions : congenital in two, acquired in two.

(6) Refraction : myopic in eight (in three of a high degree) hypermetropic in two.

(7) Vision: as good as if there had been no pigment.

(8) Sex : female in eight, male in two.

(9) Age when first observed : 22 to 45 in eight, over 60 in two.

(10) Progress of the condition : those cases that were seen after a lapse of years showed no advance or retrogression.

\section{Aetiology}

There is some difference of opinion as to whether the condition is congenital or acquired.

(1) Congenital. - This view is favoured by Thomson and Ballantyne, who adduce the following arguments in its support :

(1) Perfect symmetry.

(2) Pigment spots of the same size.

(3) Pigment is interstitial and not on either surface of the cornea.

(4) No past history or indication of inflammation.

(5) The eyes are myopic.

(2) Acquired.-Krukenberg and Stock regarded the condition as being on the posterior surface of the cornea and derived from the pigment of a persistent pupillary membrane, which, once attached to the posterior surface of the cornea, had left this indication of its attachment. Vogt also considers the condition to be acquired.

\section{Cases of Persistent Pupillary Membrane with adherence to the Cornea}

Of 20 recorded cases, 12 were attributed to imperfect division of mesoblast, and 8 to keratitis with or without perforation. In some, fibres were observed running from the corneal opacity to the circulus iridis minor, in others, the corneal ends of the strands were unattached, and it was these latter cases that were thought to mark an intermediary stage between an attached pupillary membrane and Krukenberg's spindles. It is difficult, however, to understand why, in the latter condition, there are no signs of a persistent pupillary membrane, and why the pigment should be so uniformly and symmetrically distributed in a vertical spindleshaped area.

\section{Acquired Pigmentation in Pseudo-sclerosis and Wilson's Disease}

These two diseases are known collectively as hepato-lenticular degeneration, and cases of them show the Kayser-Fleischer ring. 
When focal light is thrown through the ring on to the iris, a golden glow is imparted to that structure as if it were illuminated by the setting sun. Examined with the slit-lamp the pigmentation is seen to be granular in the deepest layers of the cornea, brown peripherally, gradually becoming yellow and fading towards the centre. The endothelial cells of the cornea are normal and the Hassel-Henle "craters" are present and normal.

Microscopical sections show the pigment to be in Descemet's membrane, immediately under the cubical endothelium, beginning at a little distance from the angle of the anterior chamber, where the limit of the pigmentation is sharply defined, and thence fading towards the centre of the cornea.

The pigment is disposed in granules of a very dense black-brown colour, finer than the pigment granules of the retinal pigment layer. It is uniformly distributed under the endothelium and does not always occupy the entire thickness of Descemet's membrane. Thus outside the pigment there is at times a thin clear zone.

The chemical composition of the pigment is a matter of discussion, the various suggestions including silver, melanin, and bilirubin; however one fact stands out, and that is that the reaction for iron is not present.

My thanks are due to Mr. Hudson for allowing me to describe the case, and to Miss Mann for her great assistance in the slit-lamp examination. The sources from which the above information was obtained are given in the bibliography.

\section{BIBLIOGRAPHY OF CASES RELATING TO CORNEAL PIGMENTATION.}

Main Reference :-

Holloway, T. B.-Congenital Pigmentation of the Cornea." Ann. of Ophthal., Vol. XIX, No. 4, Oct., 1910.

DESCRIPTION OF CASES :-

Krukenberg.-1st case, Klin. Monatsbl. f. Augenheilk., Vol. XXXVII, p. 254, 1899.

2nd case, Ibid,., p. 478.

3rd case, Ibid., p. 478.

Stock.-Klin. Monatsbi. f. A ugenheilk., Vol. XXXIX, Pt. ii, p. 770, 1901.

Thomson and Ballantyne.-Trans. Ophthal. Soc. U.K., Vol. XXIII., p. 274, 1903.

Kraemer.-Ann. of Ophthal., Vol. XV, p. 390, 1906.

Congenital or Acquired Origin Discussed :-

Pier.-Inaug. Diss., Giessen, 1906.

Wüstefeld.-Zeitschr. f. Augenheilk., Vol. IV, p. 590, 1900.

Bohm.-Inaug. Diss., Giessen, 1902.

Pigmentation of the Posterior Surface of the Cornea in Old People With Cataract :-

Goldberg.-Klin. Monatsbl.f. Augenheilk., p. 324, Oct., 1907. 
DEVELOPMENT OF THE EYE:-

Kollicker.-Entwickelungsgeschichte des Menchen.

Parsons.-Pathology of the Eye, Vol. III, p. 904.

Hertwig.-Lehrbuch der Entwickelungs Geschichte, 1906.

Jeannulatos. - Thèse de Paris, 1896.

Collins.-Roy. Lond. Ophthal. Hosp. Rep., p. 305, 1895-97.

Nussbaum.-Graefe-Saemisch Handbuch, Vol. II, 1900.

Lange.-Ein Blick in die Embryonale Anatomie und Entwickelung des Menchenauges.

Persistent Pupillary Membrane Adherent to the Cornea, due to Defective Development :-

Makrocki.-Arch.f. Augenheilk. Vol. XIV, p. 83, 1884-5.

Collins.-Lancet, Vol. II, p. 1463, 1894.

Vossius.-Deutschmann's Beiträge, Vol. I, p. 717.

Collins.-Trans. Ophthal. Soc. U.K., Vol. XXVII, p. 203, 1907.

Wüstefeld.-Zeitschr. f. Augenheilk., Vol. IV, p. 590, 1900.

Polte.-Arch.f. Augenheilk., Vol. XLVIII, p. 80, 1903.

Rumschewitsch.-Arch. f. Ophthal.,Vol. XXXVII, p. 595, 1908.

Schonte.-Zeitschr. f. Augenheilk., Vol. III, p. 230, 1900.

zur Nedden.-Klin. Monatsbl. f. Augenheilk., Vol. XLI. Pt. ii, p. 230.

von Hippel.-Arch.f. Ophthal., Vol. LX, p. 444, 1905.

Persistent Pupillary Membrane Adherent to Cornea, due to INFLAMMATION :-

Arlt.-Die Krankheiten des Auges, Vol. I, p. 235.

Samelson.-Centralbl. f. prakt. Augenheilk., p, 215, 1880.

Wintersteiner.-Wien. Klin. Wochenschr., Vol. VI, p. 508, 1893 ; and Arch. f. Ophthal., Vol. LVII, p. 53, 1903.

Gesang.-Deutschmann's Beiträge, p. 342, 1904.

Zirm.-Klin. Monatsbl. f. Augenheilk., Vol. XXVIII, p. 288, 1890.

Schapringer.-New Yorker Med. Monatschrift., Vol. XII, p. 591, 1900.

van Duyse.-Ann. d'Ocul., Vol. XCV, p. 24, 1886.

Ballantyne.-Trans. Ophthal. Soc. U.K., Vol. XXV, p. 319, 1905.

Persistent Pupillary Membrane Adherent to Cornea, due to Keratitis

FoEtal or POST-Natal :-

von Hippel.-Graefe-Saemisch Handbuch, 1900; and Arch. f. Ophthal., Vol. LII, p. 473, 1901.

INTERSTITIAL KERATITIS WITH ANTERIOR SyNechiaE Without

Perforation.

Schweigger.-Arch.f. Augenheilk., Vol. XVII, p. 403, 1886-7.

Cases Intermediate between Persistent Pupillary Membrane and KRUKENBERG'S SPINDLES :-

Brückner.-Arch.f. Augenheilk., Vol. LVI, p. 5, 1907.

Anatomy of Persistent Pupillary Membrane:-

Rumschewitsch.-Arch. f. Augenheilk., Vol. XX, p. 314 ; and Arch. f. Ophthal., Vol. XXXVII, p. 595, 1908.

von Hippel.-Graefe-Saemisch Handbuch, 1900.

Hirschberg.-Centralbl. f. prakt. Augenheilk., Vol. XXVIII, p. 103, 1904.

Freely Movable Pigmented Masses in Anterior Chamber :-

Apetz._Zeitschr. f. Augenheilk., Vol. IV., p. 593, 1900.

Businelli.-Ann. d'Ocul., Vol. LIV-LX, p. 168, 1868.

Troitski.-Arch.f. Augenheilk., Vol. XVII, p. 451, 1886-7.

Acquired Deep Pigmentation of the Cornea. (c.f. Hepato-lenticular degeneration, infra) :-

Fleischer.-Klin. Monatsbl. f. Augenheilk., Vol. XLI, Pt. i, p. 489, 1903.

Salus.-Med. Klin., Vol. IV., p. 498, 1908. 
Ragged Anterior Surface of Iris with Pigmented Portion of Iris AdHERENT TO THE CORNEA :-

Fisher.-Trans. Ophthal. Soc. U.K., Vol. XXI, p. 166, 1900.

Congenital Superficial Pigmentation of the Cornea :-

Westhoff.-Centralbl. f. prakt. Augenheilk., Vol. XXII, p. 248, 1898.

Kraemer.-Ann. of Ophthal., Vol, XV, p. 239, 1906.

Steiner.-Centralbl.f. prakt. Augenheilk., Vol. XXIX, p. 293, 1905.

Unilateral deep Pigmentation of the Cornea ? Congenital ? Nafyus ? NEOPLASM :-

Klein.-Zeitschr. f. Augenheilk., Vol. XX, p. 76, 1908.

Hepato-Lenticular Degeneration:-

Barnes and Hurst.-Brain, Vol. XLVIII, Pt. iii, 1925.

Goulden and Harris.-Koby's Slit-Lamp Microscopy of the Living Eye.

\section{SPONTANEOUS ABSORPTION OF MATURE SENILE CATARACT}

BY

\section{A. J. Ballantyne \\ GLASGOW}

THE following case illustrates a form a spontaneous cure of cataract which is new in my experience and may be of interest to others.

The patient, a lady about 65 years of age, had a mature cataract removed from her left eye 13 years ago by the late Dr. Cluckie of Paisley. She states that at that time the right eye was already affected, and that it became progressively dimmer, until three or four years ago when she consulted Dr. T. S. Barrie of Glasgow, and was told that she had now a mature cataract in the right eye. She has had no treatment since that date, but the vision of the right eye has gradually returned, and about two months ago she began to see double.

On examination I found that the left eye was aphakic, the pupil a little drawn towards the nasal side (a simple extraction having been performed), the media were clear and the fundus normal. Vision in the left eye with +9D.sph. $0+3.5 \mathrm{D} . c y l$. axis $180^{\circ}=5 / 6$. Ophthalmoscopic examination in the right eye (which was slightly divergent) detected a little fine dust-like opacity in or behind the pupil. The fundus could be fairly clearly seen, and the refraction was highly hypermetropic. Vision in the right eye with +11D. sph. $0+0.5 \mathrm{D}$. cyl., axis $180^{\circ}=5 / 12$. The result of the subjective test and of the ophthalmoscopic examination gave me the impression that the lens of the right eye was for some reason absent, but examination with the slit-lamp revealed a somewhat unexpected 